\title{
True Happiness in the Presence of YHWH: The Literary and Theological Context for Understanding Psalm 16
}

\author{
Phil J. Botha (University of Pretoria)
}

\begin{abstract}
This article attempts to interpret Ps 16 as part of the cluster of Psalms 15-24, but also as a Torah-wisdom psalm. Hossfeld and Zenger have argued that Ps 16 was added to this cluster simultaneously with Pss 19 and 23, but that this happened quite some time before Ps 1 was composed to serve (together with Ps 2) as the preface to the whole Psalter. It is proposed here that Ps 16 is a Torahwisdom composition which exemplifies true blessedness as compliance with the Torah of YHWH in contentedness with one's lot in life. It thus represents the kind of piety also portrayed in other Torahwisdom psalms such as Pss 1, 19, 23 and 73. It is consequently suggested that Ps 16 is much closer to Ps 1 in time of origin and teaching as has been accepted until now. This does have implications for its interpretation.
\end{abstract}

\section{A INTRODUCTION}

The insight that individual psalms should be studied on their own but also within their literary context, can largely be attributed to the work of FrankLothar Hossfeld and Erich Zenger. ${ }^{1}$ But, despite the tremendous advances in understanding a psalm like Ps 16 which were made possible through their work, some further reflection still seems necessary. Psalm 16 is part of a cluster of psalms comprising the concentric collection 15-24, and according to Hossfeld and Zenger, 16, 19, and 23 were only added to this already existing cluster during the fifth to fourth centuries B.C.E. ${ }^{2}$ This date seems to be too early, however, since these three "late" additions to the collection all display a depend-

* Article submitted: 23/02/2016; article accepted: 3/03/2016. Phil J. Botha, "True Happiness in the Presence of YHWH: The Literary and Theological Context for Understanding Psalm 16," OTE 29/1 (2016): 61-84. DOI: http:// dx.doi.org/10.17159/2312-3621/2016/v29n1a5

1 The reasons for such a dual approach are set out convincingly in Erich Zenger, "Psalmenexegese und Psalterexegese: Eine Forschungsskizze," in The Composition of the Book of Psalms (ed. Erich Zenger; BETL 238; Leuven: Peeters, 2010), 17-65.

2 Cf. Frank-Lothar Hossfeld and Erich Zenger, Psalm 1-50 (vol. 1 of Die Psalmen; NEchtB; Würzburg: Echter Verlag, 1993), 14. They later describe the psalm simply as post-exilic ("nachexilisch"), p. 109. 
ence on and a development from the teaching found in Proverbs. ${ }^{3}$ It seems that Proverbs was already in existence and had been accepted as authoritative teaching by the time these three psalms were composed. If that is the case, their origin must probably be assigned to the beginning of the Hellenistic age, in other words, to more or less the same date as that assigned to Ps 1 by Hossfeld and Zenger.

According to Hossfeld and Zenger, the Psalter began with a collection of (late) pre-exilic prayers $(3-7,11-14,17-18,20-22,26-28,30-31,35,38,41)$, arranged in four clusters during the early post-exilic period. ${ }^{4}$ The redaction who collected these psalms expanded the four clusters by adding more pre-exilic or exilic psalms as well as psalms which they themselves composed $(8,15,24,29$, $32,36) .^{5}$ Another redaction, dated by them in the fifth to fourth century B.C.E., then expanded the exilic and early post-exilic composition by adding 16, 19, $23,25,33,34,37,39$, and $40 .{ }^{6}$ In the meantime, Pss $42-88$ were being collected separately and from a variety of sources ${ }^{7}$ which need not be discussed within the scope of this article. Psalms 3-41 were joined to 42-88 and (the original form of) Ps 2 was subsequently inserted before the collection 3-89 by the third

3 In the case of Ps 16, Hossfeld and Zenger assign a post-exilic date because of the sapiential atmosphere ("weisheitliche Kolorit") present in themes such as "my wellbeing" in $2 b$; the idea of a plan for one's life and nocturnal guidance in 7-8; the image of the road of life in 11; and also the connections with Trito-Isaiah in 3-4 as well as connections with the Deuteronomistic redaction of Jeremiah in the psalm. Cf. Hossfeld and Zenger, Psalm 1-50, 109. Kathrin Liess, Der Weg des Lebens: Psalm 16 und das Lebens- und Todesverständnis der Individualpsalmen (FAT II/5; Tübingen: Mohr Siebeck, 2004), has subsequently explored the wisdom influence on Ps 16 in much greater detail. She shows (pp. 237-242) how the "way of life," ארח חיים, is a concept found in both the older and the younger parts of Proverbs and how its use in Proverbs clarifies the meaning of the expression in Ps 16. The antithesis between the "way of life" and the sphere of death in Proverbs and its simultaneous reference to the correct way of conducting one's life can only point to Proverbs as the contextual background for Ps 16. She points out that in Ps 16, YHWH has taken over the role of the father or teacher who serves as the adviser on the way of life in Proverbs. The emphasis in Ps 16 is also not on the correct conduct, but on the state of life ("Ergehen") of the suppliant (Liess, Der Weg des Lebens, 243). The implication of this, in my view, is that Ps 16 displays a development from wisdom motifs found in Proverbs. Psalms 19 and 23 display similar wisdom features and both have also been shown to be dependent on Proverbs. Concerning Ps 19, cf. Bernard Gosse, "Le livre des Proverbes, la Sagesse, la Loi et le Psautier," ETR 81 (2006): 387-394. Concerning Ps 23, cf. Phil J. Botha, "Following the 'Tracks of Righteousness' of Psalm 23," OTE 28 (2015): 283-300.

4 Hossfeld and Zenger, Psalm 1-50, 14.

5 Hossfeld and Zenger, Psalm 1-50, 14.

6 Hossfeld and Zenger, Psalm 1-50, 14.

7 Cf. Hossfeld and Zenger, Psalm 1-50, 15. 
century B.C.E. ${ }^{8}$ Ps 2 itself was then edited to form a unity with Ps 1 (which was composed purposefully for its present position) in order to create a two-psalm preface to the book of Psalms as a whole. ${ }^{9}$ From this exposition abstracted from the work of Hossfeld and Zenger it would seem that Ps 16 possibly antedates Ps 1 by a margin of one to two centuries. Yet, the theological ambience of Ps 16 and its dependence on Proverbs rather suggest that its time of origin (as is the case with 19 and 23) must have been closer to that of Ps 1 .

The aim with this article is to attempt to understand the reasons why Ps 16 was composed and inserted in its present position in the Psalter and when this happened. To achieve this, it will be necessary to analyse the form and contents of the psalm again. In the view of the present author, there are some deficiencies in the exposition of the psalm by Hossfeld and Zenger which need to be re-evaluated. ${ }^{10}$ It is also necessary to recognise that Ps 16 is a didactic wisdom composition, a Torah-wisdom psalm, ${ }^{11}$ very similar to Pss 19 and 23, and consequently also to Ps 1 . As part of the cluster 15-24, it further needs to be interpreted in comparison with Pss 19 and 23. In this regard, much work has been done by others which will be repeated and possibly expanded upon here. Finally, the time of writing and the connection with other Torah-wisdom psalms, such as Ps 1, will be investigated in order to be able to make a conclusion about its contribution to the Psalter as it appears in the "final" MT.

8 Cf. Hossfeld and Zenger, Psalm 1-50, 45.

9 Hossfeld and Zenger, Psalm 1-50, 45.

10 This concerns especially the translation of v. 3, which is understood by them to refer to pious followers of YHWH and not idols. Liess, Der Weg des Lebens, 51 and Beat Weber, "Notizen zu Form, Pragmatik und Struktur von Psalm 16," BN 125 (2005): 25-38, 26, both also concur with the interpretation of Hossfeld and Zenger, Psalm 1-50.

11 With the designation "Torah-wisdom" psalms, I refer to psalms which cast YHWH (or the psalmist) in the role assigned to a wisdom teacher in Proverbs, so that YHWH is portrayed as the one who ultimately gives guidance on the way of life through his Torah. A variety of traditional Gattungen were employed and sometimes mixed in composing these psalms. Many of them are acrostics and the contrast between righteous people and the wicked, as well as the portrayal of life as a journey, are often found in them. Psalms 1, 16, 19, 23, 25, 32, 33, 34, 37, 49, 73, 111-112, 119 and some others can be included under this heading. In contrast to this broader interpretation, it is sometimes asserted that there are only three Torah-psalms (1,19 and 119) and that they form a subset of wisdom psalms (such as $1,37,49,73,112$, and 128). Cf. W. Dennis Tucker, "Psalms 1: Book of," DOTWPW: 585. 
Psalms 15-24 are demarcated as a unit through the clear similarities between the "cornerstone" psalms of the cluster, namely 15 and $24 .^{12}$ Together they describe the coming of the king of the world, YHWH, to the congregation constituted of worshippers who comply with the "requirements" formulated in 15:1-5 and 24:1-6. Psalm 19 forms the "capstone" of the "arch" formed by 1524. With its connections to both 15 and $24,{ }^{13}$ Ps 19 confesses that YHWH is the one who facilitates a life of righteousness and explains how he does it, namely by inviting acceptance of the encompassing order of world and life which he has revealed in creation (19:1-7) and in his Torah (19:8-15). ${ }^{14}$ The psalms of this cluster are arranged concentrically around Ps 19 (20-21 must be read together to facilitate this), so that 16 and 23 form a corresponding pair (both are declarations of trust) with numerous connections between them. According to Hossfeld and Zenger, the cluster 15-24 in its present form outlines the ideal image of the "righteous," confirming also that this is the person who receives help and salvation from YHWH. ${ }^{15}$

In the words of one investigator, the collection 15-24 is said to focus on the Torah of YHWH, with obedience to divine instruction forming the hallmark of the collection. ${ }^{16}$ Piety as religious zeal is therefore a conspicuous feature of the collection 15-24. While the cluster 3-14 is characterised by persecution and suffering and contains many complaints about oppressors, 15-24 focus much more on the positive aspects of worshipping YHWH. Dedication to YHWH through the Torah and the joy of being in his presence in 15-24 can be viewed as the obverse side of the seeming absence of YHWH and the resulting injustices and oppression complained about in 3-14. In the present form of the Psalter, it seems that 3-14 provide an exposition of the contents of Ps 2: The theme in these psalms is (broadly speaking) the revolt of wicked, powerful people against the reign of YHWH and his anointed because they think YHWH is powerless (cf. 2:2-3), although the certainty of victory for the anointed of YHWH

12 For an overview of how the idea of a concentric cluster in 15-24 developed, see the fine summary of Philip Sumpter, "The Coherence of Psalms 15-24," Bib 94 (2013): 186-209, 186-192.

13 The reference to the "servant" of YHWH's conduct in 19:12-14 has connections to both 15:2 and 24:4, according to Hossfeld and Zenger, Psalm 1-50, 13.

14 Hossfeld and Zenger, Psalm 1-50, 13.

15 Hossfeld and Zenger, Psalm 1-50, 13.

16 Alphonso Groenewald, "The Ethical 'Way' of Psalm 16," in The Composition of the Book of Psalms (ed. Erich Zenger; BETL 238; Leuven: Peeters, 2010), 505. Groenewald refers in this regard also to Patrick D. Miller, "Kingship, Torah Obedience and Prayer," in Neue Wege der Psalmenforschung: Für Walter Beyerlin (ed. Klaus Seybold and Erich Zenger; HBS 1; Freiburg: Herder, 1994), 127. 
and his people is also emphasised (cf. 2:4-9). ${ }^{17}$ The cluster consisting of 15-24, in contrast, seems rather like an exposition and application of the teaching of Ps 1: The theme is true blessedness (cf. 1:1) and contentedness in the presence of YHWH (cf. 1:3 and 6) and how to achieve that privilege through the guidance of the Torah of YHWH (cf. 1:2). ${ }^{18}$

This article now aims, first, to demonstrate how Ps 16 (as a declaration of wholehearted dedication to YHWH and contentment in his presence) fits into the composition 15-24 with its focus on the Torah and, second, how it links up with some of the other Torah-wisdom psalms. To achieve this aim, it will be analysed as a composition sui generis and then also as part of the composition 15-24. A third part will attempt to describe how it relates to other Torah-wisdom psalms in defining true blessedness as a journey in which the Torah guides the believer towards the presence of YHWH. At the end, an attempt will be made to assign a date of origin to Ps 16.

\section{B THE TEXT, FORM AND CONTENTS OF PSALM 16}

In terms of its genre, Ps 16 can be described as the confession of a happy person who knows that his well-being depends exclusively on God. Hossfeld and Zenger, on the other hand, infer from the structure and speech dynamics of Ps 16 that it is

a prayer of supplication of an individual who, in the midst of deepseated anxiety in life, clings to his fundamental option of embracing YHWH as his personal patron god and puts his hope for good fortune on the road of life only in him. ${ }^{19}$

17 Cf. the essay of Friedhelm Hartenstein, “'Schaffe mir Recht, JHWH!' (Psalm 7:9): Zum theologischen und anthropologischen Profil der Teilkomposition Psalm 3-14," in The Composition of the Book of Psalms (ed. Erich Zenger; BETL 238; Leuven: Peeters, 2010), 229-258, who points out the connection between the enemy pronouncements in 3:3 and 14:1 about the absence of help and the absence of God, and the contrasting parallel exclamations of trust in 3:9 and 14:6 that YHWH will certainly help. The term רשע, "wicked," for example, occurs 16 times in Pss 3-14 and only three times in Pss 15-24.

18 For the role of the Torah in Ps 16, see below. Since Ps 1 was probably added after the first Davidic Psalter was put together, any correspondence between Ps 1 and Pss 15-24 points to the same or similarly minded editors at work in the composition of Ps 1 and the editing of Ps 15-24.

19 "Achtet man auf Struktur und Sprechdynamik des Psalms, kann man ihn am ehesten als Bittgebet eines einzelnen bezeichnen, der inmitten tiefsitzender Lebensangst an seiner fundamentalen Option für JHWH als seinem persönlichen Schutzgott festhält und von ihm das Glücken seines Lenbensweges erhofft." Hossfeld and Zenger, Psalm 1-50, 108. 
Verses 1, 5 and 10-11 can indeed be described as a prayer, but the purpose of the psalm seems to be wisdom teaching which defines righteousness as complete happiness in the presence of YHWH and under the guidance of his Torah. ${ }^{20}$ In this regard, it seems more like an explication of Ps 1 than the prayer of an anxious person. The suppliant displays very little of that "deep-seated anxiety" and "hope for good fortune" which Hossfeld and Zenger mention, but rather complete contentedness and certainty that YHWH alone is enough.

The psalm can be separated into two stanzas (I and II), each with three strophes which form a parallel structure (A, B and C corresponding to A', B' and $\left.C^{\prime}\right)$. Unfortunately, it is one of those chapters of the HB which cannot be interpreted without slight emendation to the text. In the following translation, the places where such changes are suggested are marked by underlining certain words (vv. 3b, 5b, and 6b). These instances are discussed below the exposition of the structure.

\begin{tabular}{|c|c|c|c|c|}
\hline & & & 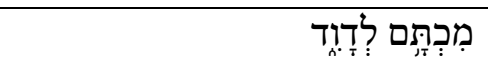 & ${ }^{1}$ A miktam of David. \\
\hline \multirow[t]{8}{*}{ I } & A & 1 & 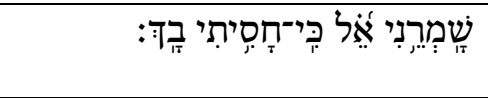 & $\begin{array}{l}\text { Protect me, O God, for in you I have } \\
\text { taken refuge. }\end{array}$ \\
\hline & & $2 \mathrm{a}$ & 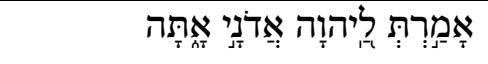 & ${ }^{2}$ I said to YHWH, "You are my Lord; \\
\hline & & $\mathrm{b}$ & 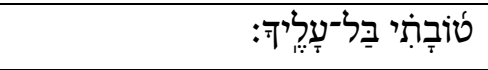 & my well-being depends only on you." \\
\hline & B & $3 a$ & 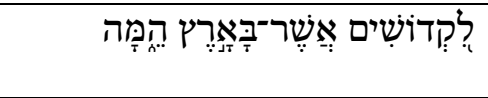 & $\begin{array}{l}\text { As for the holy ones that are in the } \\
\text { land, }\end{array}$ \\
\hline & & $\mathrm{b}$ & 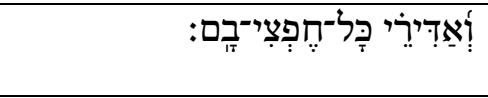 & $\begin{array}{l}\text { and the magnificent ones in whom I } \\
\text { have no delight: }\end{array}$ \\
\hline & & $4 a$ & 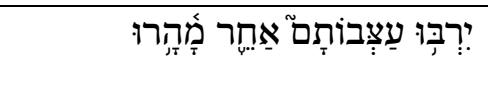 & $\begin{array}{l}{ }^{4} \text { They multiply their sorrows, those } \\
\text { who acquire another (god); }\end{array}$ \\
\hline & & $\mathrm{b}$ & 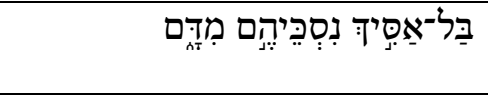 & $\begin{array}{l}\text { I will not pour out their libations of } \\
\text { blood }\end{array}$ \\
\hline & & $\mathrm{c}$ & 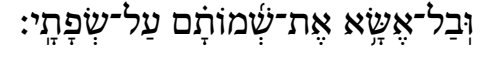 & and not take their names on my lips. \\
\hline
\end{tabular}

20 It shows similarity to Ps 73 which also seems like a confession in vv. 1-17 but then naturally develops into a prayer-like dedication and declaration of faith in vv. 1828. Psalm 16 reflects elements of supplication, invocation, and a declaration of trust, but also lament and thanksgiving (for an overview, cf. Liess, Der Weg des Lebens, 106-107). This mixing of Gattungen seems to point to its origin in a literary setting rather than one of the classical Sitze-im-Leben, although Liess is not willing to choose between the possibility of its originating in the temple or outside of it (Liess, Der Weg des Lebens, 290). Cf. the response of Weber, "Notizen zu Form," 34 to her description. Weber opts to choose for a context of origin in the temple on the grounds of (inter alia) a supposed address to the congregation in 4a and 7-9 as well as the rejection of heathen cults in $4 \mathrm{bc}$. In my view, the psalm was intended as instruction. The presence of an audience does not require that it had to be presented in the temple. 
Botha, “True Happiness,” OTE 29/1 (2016): 61-84

\begin{tabular}{|c|c|c|c|c|}
\hline & $\mathrm{C}$ & $5 \mathrm{a}$ & 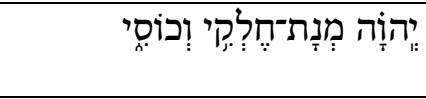 & $\begin{array}{l}{ }^{5} \text { YHWH is the portion of my possession } \\
\text { and my cup; }\end{array}$ \\
\hline & & $\mathrm{b}$ & 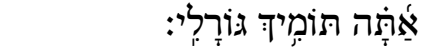 & you take hold of my lot. \\
\hline & & $6 a$ & 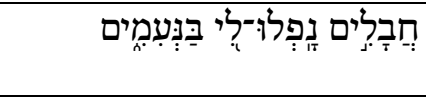 & $\begin{array}{l}{ }^{6} \text { The cords have fallen for me in } \\
\text { pleasant places; }\end{array}$ \\
\hline & & $\mathrm{b}$ & 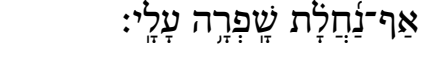 & indeed, this inheritance pleases me well. \\
\hline \multirow[t]{11}{*}{ II } & $\mathrm{A}^{\prime}$ & $7 \mathrm{a}$ & 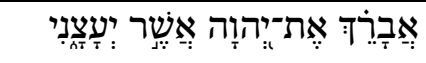 & ${ }^{7}$ I praise YHWH who counselled me; \\
\hline & & $\mathrm{b}$ & 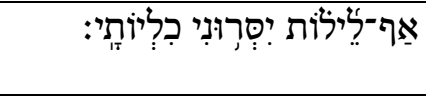 & $\begin{array}{l}\text { even during the nights my kidneys } \\
\text { instruct me. }\end{array}$ \\
\hline & & $8 \mathrm{a}$ & 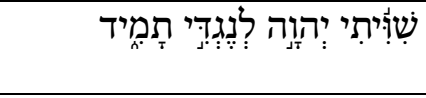 & $\begin{array}{l}{ }^{8} \text { I have set YHWH before me } \\
\text { continually; }\end{array}$ \\
\hline & & $\mathrm{b}$ & 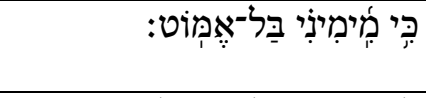 & $\begin{array}{l}\text { because he is at my right hand, I shall } \\
\text { not be made to stumble. }\end{array}$ \\
\hline & $\mathrm{B}^{\prime}$ & $9 \mathrm{a}$ & 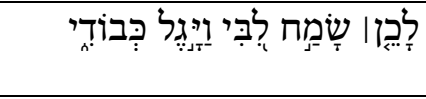 & $\begin{array}{l}{ }^{9} \text { Therefore my heart is glad, and my } \\
\text { honour rejoices; }\end{array}$ \\
\hline & & $\mathrm{b}$ & 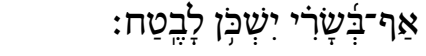 & yes, my flesh will dwell in safety. \\
\hline & & $10 \mathrm{a}$ & 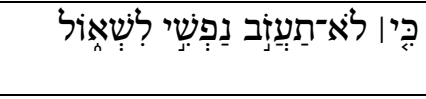 & $\begin{array}{l}{ }^{10} \text { For you will not abandon my soul to } \\
\text { Sheol, }\end{array}$ \\
\hline & & $\mathrm{b}$ & 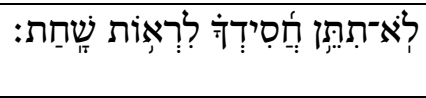 & $\begin{array}{l}\text { nor relinquish your faithful follower to } \\
\text { see the pit. }\end{array}$ \\
\hline & $\mathrm{C}^{\prime}$ & $11 \mathrm{a}$ & 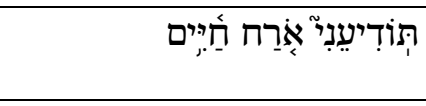 & $\begin{array}{l}{ }^{11} \text { You make known to me the path of } \\
\text { life; }\end{array}$ \\
\hline & & $\mathrm{b}$ & 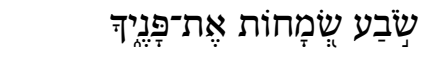 & satiation of joys is in your presence; \\
\hline & & $\mathrm{c}$ & 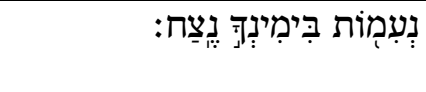 & $\begin{array}{l}\text { pleasant things in your right hand } \\
\text { forevermore. }\end{array}$ \\
\hline
\end{tabular}

\section{$1 \quad$ Notes on the Translation}

$2^{a}$ : The reading of MT אמרת is understood as equivalent to אמרתי. According to Hossfeld and Zenger, the Masoretes thought with this vocalization about Israel as a woman or lady servant of God. They refer to the Targum which expands it to "You, my soul, have said." 21 Klaus Seybold considers it to be simply the (unvocalized) Aramaic form of the first person singular. It would thus originally have been read as אַמְרֵת ,I said."22

$3^{\mathbf{b}}$ : Vv. 3-4: The received text cannot be translated or understood completely if it is not emendated. אדירי is emendated to read אדירים. According to Hossfeld and Zenger, these verses should probably be described as a later addition which expands the exclusive dedication made to YHWH in v. 2 by promis-

21 Cf. Hossfeld and Zenger, Psalm 1-50, 110.

22 Klaus Seybold, Die Psalmen (HAT I/15; Tübingen: J. C. B. Mohr [Paul Siebeck], 1996), 70. 
ing faithfulness to the congregation ${ }^{23}$ in v. 3 and by formulating an abrenuntiatio (absolute renunciation or repudiation) of other cults in v. 4. Hossfeld and Zenger point out the (conspicuous) similarities of v. 4 with Isa 57:6 and 66:3. As such it would fit into the late post-exilic (Hellenistic) era. ${ }^{24}$ The reference to "another" is understood by them as "another god," possibly alluding to Exod $34: 14{ }^{25}$ But interpreting v. 3 in this way as a declaration of loyalty to fellow believers clashes with the contents of the rest of the psalm, and especially with the immediate context in vv. 2 and $4 .^{26}$ The author rather seems to emphasize his exclusive dedication to YHWH. With Johannes van der Ploeg and various other interpreters it seems better to accept that כל כל כ originally was written as, and that this negation (which is also used in vv. 2, 4, and 8) was lost when it was no longer understood that "holy ones" and "magnificent ones" referred to the "holy" beings or spirits which were worshipped by others and with whom the author would have no connection. ${ }^{27}$ Such an emendation also re-establishes the logical sequence between vv. 2 and 3 and the parallel between vv. 3 and 4 . The similarity of v. 2 ("I said to YHWH, 'You are my Lord; my well-being depends only on you'") to Ps 73:25 ("Whom do I have in heaven but you? And there is nothing on earth that I desire besides you") also speaks against the use of חפץ in v. 3 (used together with בארץ) as applicable to anything but the expression of whole-hearted dedication to YHWH alone. In Ps 1:2, the cognate noun חפץ is similarly used to express whole-hearted dedication to the Torah of YHWH.

4": "Acquire": the root of the verb is probably II מהר, to acquire (through payment of the ממהרר) a wife (and possibly to exchange one idol for

23 According to him, the communio sanctorum is referred to as the "holy" and "magnificent" ones.

24 Cf. Hossfeld and Zenger, Psalm 1-50, 108 and 111.

25 See Hossfeld and Zenger, Psalm 1-50, 108.

26 This difficulty is perceived by Liess, Der Weg des Lebens, 50, but she persists in claiming that vv. 2-4 contain a threefold confession before God: The suppliant "bekennt sich zu JHWH, zu den Heiligen, und er bekennt sich - in negativer Richtung - zur Ablehnung der Fremdgötterverehrung."

27 Johannes P. M. van der Ploeg, Psalm $1 \mathrm{t} / \mathrm{m} 75$ (vol. 1 of Psalmen; BOT; Roermond: J. J. Romen \& Zonen, 1973), 106 mentions the following interpreters as proponents of this view: Lagrange, Coppens-Dequeker, Ehrlich, Gunkel, Leslie, Podechard, Nyberg and Maillot-Lelièvre. He refers to Hos 12:1 and 1 Sam 4:8 as instances where are used respectively as descriptions for gods. The first-mentioned word is used to describe angelic beings in Ps 89:6 and 8. Seybold, Die Psalmen, 71, also considers the words to refer to "Numina und Dämonen" rather than fellow worshippers and members of the same people. 
another ${ }^{28}$ through payment or gift), and not I מהר, to hurry (it has this meaning only in the pi'el).

5': תומיך is emendated to תומך and read as the active participle of the qal. מנת is an Aramaism. ${ }^{29}$

$6^{\mathbf{b}}$ : According to Hossfeld and Zenger, ${ }^{30}$ נחלת can be retained as a special form of נחלה and translated as "this inheritance." שפרה is another Aramaism, cf. Dan 4:24. ${ }^{31}$

$\mathbf{7}^{\mathbf{b}}$ : "Kidneys" here serve as the seat of sensibility (discernment, understanding) and individuality - they serve as nocturnal teachers which sharpen the guidance given by YHWH on the road of life. In this I follow the view of Hossfeld and Zenger. ${ }^{32}$

9': There is not enough justification to change "my honour" to "my liver" in the sense of "my inner-being." Many interpreters make the change on the assumption that the mentioning of so many other body parts ("heart," "flesh," "soul," "kidneys") requires or warrants the change.

11": The expression "satiation of joys" is understood as a superlative metaphor: Joy so intense that the subject is at risk of a sensory overload if more should be added. The plural forms in both cola serve the same purpose. Van der Ploeg remarks that the feminine plural is a hapax (the masculine plural is used in v. 6). In his view, the feminine form is more abstract, more elevated. ${ }^{33}$ This then implies progression from stanza I to stanza II.

\section{$2 \quad$ Notes on the Structure of Psalm 16}

Verse $1 \mathrm{~b}$ seems to be an introductory monocolon, containing a supplication for protection because the suppliant has taken refuge in YHWH. ${ }^{34}$ It is the only supplication in a psalm in which the prevalent style is that of confession (as teaching) and thanksgiving. For this reason, and because it uses the address "God" instead of YHWH, v. 1b could be considered as an editorial expansion

28 This is also one possibility considered by Seybold, Die Psalmen, 70.

29 Cf. Van der Ploeg, Psalmen I, 108.

30 Hossfeld and Zenger, Psalm 1-50, 110.

31 Van der Ploeg, Psalmen I, 108.

32 Hossfeld and Zenger, Psalm 1-50, 112.

33 Van der Ploeg, Psalmen I, 109.

34 Pieter van der Lugt, Cantos and Strophes in Biblical Hebrew Poetry, with Special Reference to the First Book of the Psalter (OtSt; Leiden: Brill, 2006), 188-194 views 1-4 and 9-11 respectively as one strophe each. The polarity between 1-2 and 3-4, the polarity between 3-4 and 9-10, and the parallel between 5-6 and 11 are reasons for separating 1-2 from 3-4 and 9-10 from 11. 
(note the use of חסהה in 17:7 and the repetition of the form שמרני in 17:8). It could thus be regarded as a heading for the whole psalm, or for the sub-group formed by Pss $16-18 .^{35}$ In the present form of the psalm this request is expanded with the declaration in 2ab that the psalmist has chosen YHWH as his Lord and that his only hope for well-being and happiness rests with YHWH. In vv. 3-4 there then follows a contrapuntal denunciation of other spiritual beings (idols and spirits) which were venerated in "the land" at the time of the composition of the psalm. A polarity is formed between "you" in $2 \mathrm{~b}$ and "they" in $3 \mathrm{a}$.

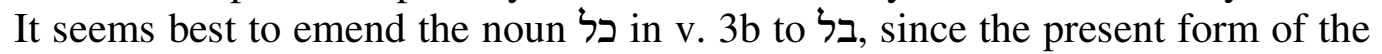
text constitutes a declaration of loyalty to co-religionists that seems to clash with v. $1 \mathrm{~b}$ as well as v. 4 (see the note on the translation supra). Strophe C (vv. 5-6) concludes the first stanza with a second reference to the name of YHWH and a direct address of YHWH (creating inclusion in the stanza). ${ }^{36}$ It describes the role of YHWH in determining the fate or fortune of the worshipper (similar to what happens in A). Stanza I as a whole can thus be described as a prayer for protection and a declaration of dependence on YHWH alone (strophe A), with explicit exclusion of other possibilities in $\mathrm{B}$ and a second description of YHWH's role in determining the fate of the suppliant in $\mathrm{C}$, using the (Levitical) metaphor of receiving YHWH as an inheritance.

Stanza II also contains two references to the name of YHWH (in vv. 7a and 8a), and another instance of the adjective נעים which was already encountered in stanza I (compare 6a with 11c). Verse 11 is thus parallel to v. 6, and the "taking hold" of the psalmist's lot in 5 is echoed in the reference to YHWH's "right hand" in 11. While stanza I can be summed up by stating that "YHWH determines my happiness, YHWH alone and no other, since he determines my fate," stanza II explains that "YHWH is my guide on the road of life, therefore I am safe and joy is mine." Strophe A' (vv. 7-8) describes the role of YHWH in the guidance of the individual on the road of life. Verse 8 is similar to v. 2, since both constitute a confession of the personal choice of the psalmist to put all his trust in YHWH alone. Strophe B' (vv. 9-10) describes the joy of life provided by YHWH's protective guidance which also protects the psalmist from death (and possibly from separation from YHWH even after death). The sorrows of those who worship other deities mentioned in v. 4 form a polarity with the joy and safety of the worshipper who puts all his trust in YHWH alone where it is mentioned in v. 9, while a parallel is formed between the double negation of v. 4 ("not pour out," "not take their names on my lips") with the double nega-

35 According to Hossfeld and Zenger, Psalm 1-50, Pss 16, 17 and 18 form a sub-unit consisting of a general prayer for protection, specific prayer for deliverance, and thanksgiving for life protection and deliverance. Note the repetition of the request for protection (also with שמרני) in 17:8. The stem חסה in turn is also used again in 17:7; $18: 3$ and 18:31, and it thus serves as a key-word.

36 Cf. the repetition of the pronoun עתה and the preposition 2a-b and 5b-6b. 
tion of v. 10 ("you will not abandon my soul to Sheol," "you will not relinquish your faithful follower to see the pit"). Strophe C' (v. 11) repeats the themes of guidance on the path of life and of the resulting joy found in strophes A' and B'. A parallel is formed between the "pleasant places" of $6 \mathrm{a}$ and the "pleasant things" of 11c, while there is also progression from the masculine plural נעמים (describing "places") in 6a to the feminine plural נעמות (describing "things") in 11c. Van der Lugt describes v. 6b as the "pivotal colon" which succinctly formulates the meaning of the psalm, namely that God's presence is the fullness of satisfaction and joy in the life of the psalmist. ${ }^{37}$

The expression "not to abandon me to Sheol" (v. 10a) and the parallel phrase "not to relinquish your faithful follower to see the pit" (v. 10b) at first glance do not seem to be exceptional for describing YHWH's role in preventing the author from dying untimely or early, such as a number of other psalm texts are also understood to imply. ${ }^{38}$ On the other hand, in a late phase of the OT development, most of these instances were also understood in terms of resurrection or eternal life, as Ps 49:16 ("But God will redeem my soul from the power of Sheol, for he will receive me") and 73:24 ("You guide me with your counsel, and afterward you will receive me honourably") ${ }^{39}$ as well as the NT application of Ps 16:10 in Acts 13:35 clearly show. ${ }^{40}$ Various investigators have pointed out that Ps 16 puts special emphasis on the status of being in God's presence as a source of (enduring) joy, and that it is but a small step from here to the belief that death would not separate the believer from God. ${ }^{41}$ In my view, there is close proximity between the language and the view of the

37 Van der Lugt, Cantos and Strophes, 191. According to him, the colon says "Yea, I am well content with my inheritance!" The formulation above is the view of Labuschagne, referred to by Van der Lugt.

38 E.g., Ps 9:14 ("you who lift me up from the gates of death"); 30:4 ("you have brought up my soul from Sheol"); 71:20 ("from the depths of the earth you will bring me up again"); 103:4 ("who redeems your life from the pit"); and 116:8 ("you have delivered my soul from death").

39 Note the seeming special use of לקח in this verse as well as Ps 73:24. KAHAL: 273 describes the use in these two verses with "(Gott) jdn. entrücken," a meaning also found in Gen 5:24 (Enoch) and $2 \mathrm{Kgs}$ 2:3 (Elijah). There are conspicuous similarities between Ps 16 and Pss 49 and 73. This makes it probable that they were composed in the same or a similar context.

40 Joseph A. Mindling, "Hope for a Felicitous Afterlife in Psalms 16, 49 and 73," Laurentianum 32 (1991): 305-369.

41 Cf. Van der Ploeg, Psalmen I, 109, who refers to Friedrich Nötscher, Die Psalmen (EB:AT; Würzburg: Echter-Verlag, 1947) and Joseph Coppens, Het onsterfelijkheidsgeloof in het Psalmboek: avec un résumé en français et une bibliographie du sujet (Brussel: Paleis der Academiën, 1957), 17. Nötscher points out the contrast between the joy of being with God and death, which entails to be separated from God, in this psalm. 
author of Ps 16 and that of Ps 73 which also emphasizes the privilege of being permanently (extending even beyond death) in the presence of YHWH. ${ }^{42}$

\section{THE GROWTH OF THE COMPOSITION 15-24}

As was mentioned in the introduction, Ps 16 is seen to be (together with 19 and 23) a late addition to the cluster $15-24 .{ }^{43}$ In the view of Hossfeld and Zenger, the first book of the Psalter came into being through a number of stages of development:

- A number of (late) pre-exilic supplications, laments and thanksgiving psalms (Pss 3-7, 11-14, 17, 18, 20, 21, 22, 26-28, 30-31, 35, 38, and 41), some of them originally still in a different form, were collected late in the exilic period or in the early post-exilic period and were further expanded by a group of editors.

- Some additional psalms (which were either already in existence or which were composed by the editors themselves, Pss 8, 15, 24, 29, 32, and 36), were then added to this collection.

- They were arranged in four smaller groups consisting of 3-14 (as yet without 9/10), 15-24 (as yet without 16, 19 and 23), 26-32 and 35-41 (as yet without 37,39 and 40 ).

- In this compendium, there was a notable self-awareness of the poor and oppressed as a group of people who endeavoured to live as righteous people. The various reasons for distress were noted and described: Persecution; poverty because of social stratification and oppression; juridical distress because of defamation, false accusations and perversion of justice; a hunger for power and brutality of the powerful and rich people; illness and personal sin.

42 Cf. Ps 73:23-28, where the psalmist says that YHWH has taken his right hand, that he leads him through his counsel (cf. 16:7), that there is no other deity like YHWH (cf. 16:2), that those who reject YHWH will suffer (cf. 16:4), and that true happiness is to be in the presence of YHWH (cf. 16:11). Liess, Der Weg des Lebens, 391-392 adds to these similarities also the fact that God is described in both psalms as the "share" (German "[Land-]Anteil") of the suppliant and his only "good." For a comprehensive discussion of the connection of Pss 16 and 73 with life after death, cf. Liess, Der Weg des Lebens, 322-402. She perceives Ps 73 to represent a further development of the experience of an intensive communion with God during one's life, reflected in Ps 16, to transcend even the boundary of life. I am not sure that one can distinguish the theology of Ps 16 from that of Ps 73 in this way.

43 Hossfeld and Zenger, Psalm 1-50, 14-15. The following exposition of the growth of Pss 3-41 reflects their views in this 1993 publication and later modifications of this theory are not accounted for. 
- In addition to laments and supplications, the collection also contained songs of thanksgiving, so that it was also characterised by a strong awareness of the certainty that the prayers of the poor and suffering are answered and that they are saved by YHWH because they are "the righteous."

- A next phase of development entailed a post-exilic redaction in the spirit of the "piety of the poor," where the poor were no longer conceived of merely as a social category, but also a religious grouping. Some of the existing psalms were edited or expanded, while a further group of psalms were integrated into the existing composition. These were Pss $16,19,23,25,33,34,37,39$, and 40 . This redaction should be located in the "fifth to fourth century."

- The objective of these editors was to depict the suppliants in these psalms as the stereotypical poor people who represent the "true Israel," people who had to contend with hostility and attack from within their own nation, their fellow Israelites. They were able to do this because they knew that YHWH and his world order (especially noted in Ps 19 and wisdom psalms such as 25, 34, 37 and 39) would eventually triumph. Through the initiative of this redaction, a deep God-mysticism was expressed especially in Pss 16, 23, and 40.

From this overview, it is thus clear that Ps 16 should be interpreted intertextually as a late (5th-4th century) editorial addition to the group consisting of 15-24 and that its connections with 19 (as the centre of the collection) and 23 (as "twin" on the other side of 19) should receive special consideration. ${ }^{44}$ The opening and closing psalms of the collection 15-24 are usually described as entrance liturgies. It is possible that they originally served this purpose, but in the present arrangement of these psalms, it would seem that they serve to define the righteous person, the paradigmatic oppressed but righteous supplicant who should be seen as the first-person speaker in the first Davidic Psalter. The questions about who has the privilege to ascend and to lodge on YHWH's holy mountain in Ps 15:1 and 24:3 are thus, in the present context, rhetorical questions aimed at the identification of the true follower of YHWH. Together with 24:6, they are designed as a response to the despair in

44 Pss 16, 19 and 23 all display pertinent wisdom influence. Hossfeld and Zenger, Psalm 1-50, 109, refer to the "weisheitliche Kolorit" of Ps 16 visible in the concept of "well-being" in v. 2; the representation of a life-plan and nocturnal guidance in vv. 78; and the "road of life" in v. 11. The connection between creation and Torah in Ps 19 is a distinct feature of late wisdom (cf. Hossfeld and Zenger, Psalm 1-50, 129). In Ps 23 , the expression "tracks of righteousness" in v. 3 can be shown to be dependent on Prov 2 as a whole. This is also a reference to the "road of life." Cf. Botha, "Following," 283-300. 
Ps 14 about the disappearance of righteous persons. ${ }^{45}$ The true follower of YHWH is described in them as someone who honours those who "fear YHWH" (15:4); part of a group of people who constitute the true "Jacob" and who "seek the face" of YHWH (24:6). In Ps 19, this person is also described as the "servant" of YHWH $(19: 12,14)$. According to the arrangement of this composi-tion, the true followers of YHWH are the people who have accepted the order in creation ordained by him (Ps 19:1-7; 24:1-2) and have subjected themselves to the guidance in YHWH's Torah $(15: 2-5 ; 19: 8-11 ; 24: 4)$.

It has been noted that the composition 15-24 also has another important focus, namely the king. ${ }^{46}$ As Barbiero has pointed out, the central psalm of the group (19) is framed by three royal psalms to which it is connected through various keywords and motifs: Ps 18 on the one side and 20-21 on the other side. ${ }^{47}$ In the context of the first Davidic Psalter, one would of course think in the first place of King David as the servant mentioned in these psalms, the model believer, who exemplifies the qualities of the righteous person described here. $^{48}$ David was unjustly persecuted by Saul and had many enemies and haters (Ps 18:1, 4 and 18), but YHWH saved him because he was "righteous" and had "clean hands" (Ps 18:21), just as Ps 24:4 says of the person who is qualified to stand on YHWH's mountain. It should be kept in mind, however, that later on the editors of the first three Books of the Psalter (1-89) effected a democratization of the language of kingship, so that the duties of the king to be a catalyst for social justice was transferred to the ordinary people. ${ }^{49}$ The piety encountered in Ps 16 was exemplified by David, but it was also the ideal for every dedicated Yahwist.

On the outside of the "royal" centre of this composition (represented by 18 and 21-22), there are two laments which form another concentric frame around Ps 19 in the middle (Pss 17 and 22). And on the outside of this circle,

45 Compare the enquiry in 14:1, God looks down from heaven to see if there are any who are wise, who seek God," and the response to this in 24:6, "This is the generation of those who seek your face, (this is) Jacob."

46 Cf. the remark of Groenewald, "The Ethical," 505 who says "[t]here is also another central focus in this collection, namely the king."

47 Gianni Barbiero, Das erste Psalmenbuch als Einheit, eine synchrone Analyse von Psalm 1-41 (ÖBS 16; Frankfurt am Main: Europäischer Verlag der Wissenschaften, 1999), 240-249.

48 Pss 15 and 24 have carefully formulated references to the sanctuary which would fit the time-frame of David, such as "tent," "holy mountain" (15:1 and 24:3), and "holy place" (24:3).

49 This process is possibly most obvious in Ps 89 where the "servants" (plural) take over from the "servant" (singular). See on this the article of W. Dennis Tucker, "Democratization and the Language of the Poor in Psalms 2-89," HBT 25 (2003): 169-163. 
and just inside the outer frame, there is the corresponding pair of Pss 16 and 23 which were thus, in the view of Hossfeld and Zenger, the last additions to the composition. The contribution of Pss 16 and 23 to the collection is, according to Groenewald and others, to paint a picture of the ideal righteous or just person, but equally important also to highlight the "saving righteousness" of YHWH; in other words, his faithful protection of the righteous oppressed. ${ }^{50}$ Kathrin Liess also describes the insertion of Pss 16 and 23, two psalms of trust, into the cluster as well-planned: initial trust (Ps 16) leads to renewed trust (Ps 23) after the experience of distress and salvation (Pss 17, 18, 22). Since these two psalms frame Pss 17-22, they serve to strengthen the view of a lasting protection and divine guidance in life even in the face of death. Even when threatened by death, YHWH remains with the suppliant, guides him or her and permits him or her participation in the fullness of life in the sanctuary $(16: 11$; 23:6). ${ }^{51}$ One aspect of Ps 16 which has possibly not been emphasised enough and which will be focused upon in the next section is the contentedness and happiness of the person whose life is under the control of YHWH and who has the right to be in his presence permanently. So great is this privilege that it diminishes any lack of material blessings and obliterates even the threat of death. Piety provides for the absence of material prosperity, as it were. This focus on contentedness provides a cue as to the aim of Ps 16 as Torah-wisdom or teaching psalm: it serves to convince fellow believers that being blessed by YHWH does not require material prosperity.

\section{THE COMBINED IMPACT OF PSALMS 16, 19 AND 23 ON THE COMPOSITION PSS 15-24}

Before the addition of these three psalms, the cluster Pss 15-24 had a strong focus on compliance with certain conditions before one could qualify to approach YHWH or be in his presence. Such conditions are spelt out in the "cornerstones" of the cluster, 15 and 24. In addition to those two so-called "entry liturgies," the collection originally contained two laments (17 and 22), which in turn embraced three royal psalms in the middle (18 and 20-21). The theme of this earlier composition (consisting of 15, 17, 18, 20-21, 22, and 24) could thus possibly have been "the suffering and triumph of the righteous king." Psalm 18, for instance, proves that King David met the criteria set by Pss 15 and $24 .{ }^{52}$ It is important to note that the composition 15-24 was adapted by the redaction who considered themselves to be the righteous poor people of

\footnotetext{
50 Groenewald, “The Ethical,” 505-506.

51 Liess, Der Weg des Lebens, 429.

52 Compare the descriptions of David as (18:24; cf. 15:2) and צמדק (18:21; cf. 15:2) in complying with the requirements of Ps 15. Cf. also the similarity between David who had "pure hands" according to 18:21 and 25 (כבר) (כרים) and the requirement of "clean hands" (נקי כפים) and a "pure heart" (בר־לבב) in Ps 24:4.
} 
YHWH, since they most probably also added vv. 26-32 to Ps 18, and vv. 24-27 to Ps 22. In these additions, they displayed the theological disposition which is also found in wisdom compositions of the poor such as Pss $25,34,37$, and $69 .{ }^{53}$

The key-word and thematic connections between Pss 16 and 23 have been explored by various investigators, and it is sufficient simply to list the most important ones: ${ }^{54}$

- The well-being of the psalmist which emanates from his relationship with YHWH (טובתי בל־עליךin 16:2 and טוב וחסד ירדפוני in 23:6);

- The "cup" of the psalmist as an indication of satisfaction with YHWH's care and the trust of the psalmist in YHwH's care (יהוה.... 16:5 and in 23:5);

- YHwh's not abandoning the "life" of the psalmist and his reviving the "life" of the psalmist (לא־תעזב נפשי in 16:10 and נפשי ישובב in 23:3);

- The privilege of continually being in YHWH's presence (כי 16:8 and כי־אתה עמדי 23:4);

- Overcoming the fear of death (16:10 and לשאול...לראות שחת in צלמות in 23:4);

- YHWH's guidance on the road of life which leads to spiritual fulfilment (in 23:3).

Through the use of these key-words and shared motifs, the idea of the psalmist's needs being completely "satisfied," so that he "lacks" nothing,

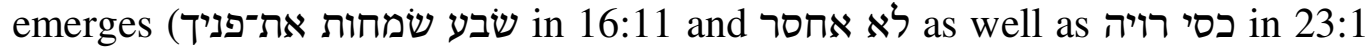
and 5). From this there flows contentment about "dwelling" in YHWH's presence "forevermore" (בשרי ישכן לבטח in 16:11; and 16:11; in 23:6). A number of investigators describe this as primarily a temple motif, ${ }^{55}$ but it is clear that the two psalms share the theme of

53 Hossfeld and Zenger, Psalm 1-50, 127 and 145. Cf. also Ulrich Berges, "'God staat aan de kant van die armen' (Ps 109,31): Armoede en rijkdom in het psalmenboek," TvT 44 (2004): 108-123,113.

54 Cf. Barbiero, Das erste Psalmenbuch, 308. Cf. in addition to this also Groenewald, "The Ethical," 509 and William P. Brown, "Here Comes the Sun!': The Metaphorical Theology of Psalms 15-24," in The Composition of the Book of Psalms (ed. Erich Zenger; BETL 238; Leuven: Peeters, 2010), 265-67. See also Liess, Der Weg des Lebens, 424-429.

55 E.g., Groenewald, "The Ethical," 509. Barbiero, Das erste Psalmenbuch, 309, is probably right in remarking that the cultic motifs are clear, although the psalms should be understood as "post-cultic." 
the psalmist's complete trust in YHWH to care for the temporal and eternal needs of the worshipper of YHWH. ${ }^{56}$ Both psalms focus at the beginning on physical needs being met and then subsequently develop the idea of spiritual contentment. Ps 16 culminates with the expression "satiation of joys" in v. 11. This was possibly meant to transcend even the state of blessedness and contentedness described in Ps 23:6.

The insertion of Ps 19 with its metaphorical comparison between the sun and the Torah ${ }^{57}$ also shifts the focus from the Torah as condition for access to YHWH towards the joy it brings. ${ }^{58}$ The Torah brings light and joy, it gives life in the presence of YHWH. The focus on the presence of YHWH in all three these wisdom psalms in the collection serve as the antithesis of the repeated allegations about the absence or inactivity of YHWH in Pss 3-14. ${ }^{59}$ Psalm 19 excels in its description of the Torah as the life-giving agent of YHWH:

"The law of YHWH is perfect, it revives the soul (משיבת נפש); the testimony of YHWH is sure, it makes the simple wise; the precepts of YHWH are right, they gladden (שמח pi 'el) the heart (לב); the commandment of YHWH is pure (ברה), it brings light to the eye" (Ps 19:8-9).

The Torah, more specifically the "precepts" (פקודים) of YHWH, "gladden" the heart (משמחי־לב, 19:9). This theme of gladness is also encountered in Ps 16: the author has a glad heart (שמח לבי, 16:9), the result of YHWH's counselling (16:7) and presence (16:8). An important aspect of YHWH's counselling and protection mentioned in Ps 16 could have been thought of as being effected precisely through the Torah. The psalmist of Ps 16 notes that even in the night his kidneys "instruct" or "discipline" him (יסר pi 'el, 16:7). This can be understood as his conscience which "disciplines" him during the night, and according to Gianni Barbiero, there is a connection here with the nocturnal

56 Barbiero, Das erste Psalmenbuch, 307, remarks that Pss 16 and 23 are connected through a hope for life on the other side of death; both end with a word which points to this hope (נצח 16:11 and לארך ימים in 23:6).

57 Cf. Brown, "Here Comes the Sun!" 261-2.

58 The sun runs its course with "joy" (ישישישי, 19:6) and the precepts of YHWH "gladden" (משמחים, 19:9) the heart.

59 Cf. Ps 3:3, "Many say of me, "There is no salvation for him in God"”; 4:7 "many say, "Who will show us any good?"; 6:5, "turn back, O YHWH!"; 10:4, all the thoughts of the wicked are "There is no God"; 12:5, "those who say, "With our tongues we will prevail, our lips are with us; who is lord over us?"; 13:2, "How long, YHWH, will you utterly forget me?"; and 14:1, "The fool says in his heart, 'There is no God."” 
meditation on the Torah mentioned in Ps 1:2. ${ }^{60}$ It is noteworthy that Ps 19:15 also refers to the "meditation" (הגיון) of the servant (cf. הגה "by day and night" in Ps 1:2). ${ }^{61}$ In addition to that, Ps 19:3 describes the nights as equally fruitful as the days in "revealing (חוה pi 'el) knowledge" about the creative work of YHWH. Psalms 16, 19, and 23 are therefore also linked to one another by similarities which they share with Ps 1 .

Contentedness and joy dominate the mood in Ps 16, and these emotions are strongly linked to the presence of YHWH. Psalm 16 speaks of both the journey in life in the presence of YHWH (16:8) and of being eventually permanently in the presence of YHWH (16:11). The same feature is also found in Ps 23 (cf. vv. 1-4 with 5-6).

Psalms 16 and 19 are both in a sense "anti-materialistic." According to

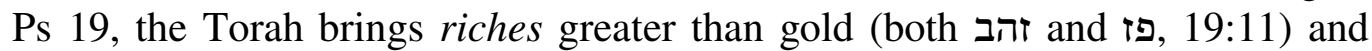
there is great reward (עקב רב) in keeping it (19:12). ${ }^{62}$ This shows great similarity to the confession that the well-being (טובה) and happiness of the suppliant of Ps 16 is determined only by YHWH and that there is no joy or pleasant place, neither a pleasant thing greater than being in the presence of YHWH. YHWH is the only possession of worth for the author of Ps 16 (vv. 5-6). The "complement" of Ps 16 in the cluster, Ps 23, can also be described as "anti-materialistic." Similar to Ps 16, it is a psalm which praises the attitude of one who can be content with being in the presence of YHWH. Where Ps 16 uses the image of a Levite whose only inheritance is the privilege of being in the presence of YHWH, ${ }^{63}$ Ps 23 uses the image of a sheep which has no concern with possessions, but only with the provision of food and drink and protection guaranteed by the presence of the shepherd (23:4). In Ps 23, the psalm also moves from the contentedness provided by YHWH's being with the suppliant on the journey through life (vv. 1-4) to the contentedness of the suppliant being with YHWH in the temple (vv. 5-6). Psalm 23 also has a link with Ps 19: In Ps 19:8, the Torah is said to "revive" the life (משיבת נפש) of YHWH's servants. In Ps 23:3, it is the shepherd who "revives" the life (נפשי ישובב) of the suppliant. Psalms 16, 19,

60 Barbiero, Das erste Psalmenbuch, 211, says that the "way of the righteous" in 1:6 is the same as the "way of life" in 16:11. It leads to life, because YHWH "knows" it

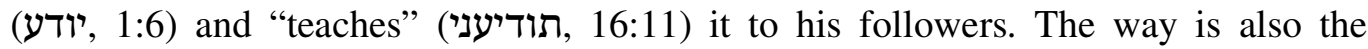
instruction of YHWH, his Torah, which educates the pious by day and by night (1:2 and 16:7).

61 The nocturnal "meditation" of the psalmist on the Torah in Ps 119:55 (to "remember" the name of YHWH and to "keep" his Torah) and 119:62 (to "praise" YHWH for his righteous rules) shows that it is not far-fetched to make this connection.

62 Prov 2:13-15, where the acquisition of wisdom is compared to the value of silver and gold, among other precious things, probably served as the inspiration for this comparison of gold with the Torah of YHWH.

${ }^{63}$ Cf. Num 18:20, Deut 10:9 and Josh 14:3. 
and 23 thus argue in unison that material prosperity is not important for those who enjoy the privilege of living in YHWH's presence.

\section{E THE CONNECTIONS OF PSALM 16 WITH OTHER TORAH- WISDOM PSALMS}

The connections established by the occurrence of certain mutual motifs in Pss 16 and 23 serve as proof that they were purposefully inserted to form a dyad within this cluster of psalms. Among these similarities are: (1) The motif of divine guidance $(16: 11 ; 23: 3)$; (2) The motif of being in the presence of YHWH even in the domain of death $(16: 8 ; 23: 4)$; (3) The temple-motif $(16: 11 ; 23: 6)$; (4) The contrast between the sphere of death and the sanctuary as sphere of life כוס occur in both psalms), these conspicuous thematic similarities point, according to Kathrin Liess, to the fact that the two psalms were not afterwards edited to form a pair, but already had thematic parallels which were simply used by an editor to serve his redactional purpose. ${ }^{64}$ The same or very similar motifs occur also in Ps 73: (1) The motif of divine guidance (73:24); (2) The motif of continually being in the presence of YHWH $(73: 23$; 28); (3) The temple-motif, since it is in the sanctuary where the psalmist gains religious insight (73:17); and (4) The contrast between being close to YHWH as being in the sphere of life forever and being far from him as being in the sphere of death (73:26-28). It is noteworthy that Ps 73:26 also uses the word "portion" to describe the relationship of the psalmist with YHWH (73:26; cf. 16:5); the word "desire" (חפץ) to describe the exclusive dedication to YHWH (73:25; cf. the emendated reading of 16:3); the "right hand" to describe the proximity to YHWH to the believer (73:23; cf. 16:8, 11); the word "glory" (כבוד) to describe the privilege of being connected to YHWH (73:24; cf. 16:9); the word "kidneys" to describe the inner considerations of the psalmist (73:21; cf. 16:7); and the adverb "always" (תמיד) to describe the enduring proximity of the psalmist to YHWH $(73: 23$; cf. 16:8). Liess ${ }^{65}$ also mentions the similarity of the motif of the "right hand" (16:8; 73:23); the similarity of the description of YHWH as counsellor ( $p$ יע 16:8; עצה 73:24); YHWH as refuge (חסה in 16:1 and מחסה 73:28); and YHWH as "only good" (16:2 and 73:25). The similarity of these motifs is perhaps more than what can be ascribed to chance. It would seem that Pss 16 and 73 have a shared context of origin and a similar purpose, namely to argue that material prosperity is not the purpose of dedication to YHWH. On the contrary, dedication to YHWH brings with it the privilege of being in his presence permanently, so that it is "impossible" to suffer any lack of "good things."

64 Liess, Der Weg des Lebens, 429. The similarities listed above were abstracted from her comparison of the two psalms, pp. 426-428. It is also possible that the two psalms were purposefully composed by the editors.

65 Lies, Der Weg des Lebens, 391-392. 
The stem "desire" (חפץ) is also used in Ps 1 to describe the dedication to YHWH, although it is the study of his Torah which is described as the delight of the righteous (1:2). Proximity to the Torah of YHWH is associated in Ps 1 with life (like a tree planted next to streams of water which guarantee its verdancy, 1:6), while lack of association with YHWH is associated with death (chaff as dead plant material and the road of life of the wicked which "perishes" in 1:4 and 6). The proximity of the righteous to YHWH as well as his guidance on the road of life is expressed with the image of the fruitful, verdant tree and of YHWH "knowing" the way of the righteous (1:6).

The aspect of happiness and joy, the "only good" of being in the presence of YHWH is also a feature of other Torah-wisdom psalms. The satisfaction it brings is sometimes compared to the joy caused by great riches and sometimes to the satisfaction caused by luxurious food. In Ps 1 , it is the Torah that nourishes the psalmist like canals of water nourish a tree (1:3). Both motifs, the Torah simultaneously giving joy and satiation, are expressed in the same verse of Ps 19, namely in 19:11. It describes the "judgements" of YHWH as "more desirable" than gold, even much fine gold, and "sweeter" than honey and drippings of the honeycomb. The riches mentioned here can be related to the "inheritance" mentioned in Ps 16:6 which "pleases" the psalmist so much, while the "honey" of Ps 19:11 is similar to the "satiation" of joy which the suppliant of Ps 16:11 experiences, as well as the prepared "table" and the "overflowing" cup of Ps 23:5.

Two of the late wisdom psalms which were added to Book I of the Psalter at more or less the same time as Pss 16, 19, and 23 also explore the themes of joy and satisfaction as gifts of YHWH. Psalm 34 describes those who look to YHWH (for help) as "shining" or "being radiant" (נהר, 34:6), and says that those who fear him have no "lack" (מין מחסור, 34:10). It adds that they "do not lack" (לא יחסרו) "any good thing" (כל־טוב, 34:11; cf. 23:6 and 73:28). Psalm 37 also emphasises the "revelling" of the righteous (ענג hitpa 'el, 37:11) in great peace and says that they will be "satisfied" (שבע, 37:19; cf. 16:11) in days of famine. This does not imply that they will be rich, but simply that YHWH will always take care of them. In Ps 37:16, we probably have the clearest formulation of the perspective also expressed in Ps 16: "Better is the little of the righteous than the abundance of many wicked."

In view of these similarities between Pss 1, 16, 19, 23, 34, 37, and 73, it seems justified to define the type of piety found in Ps 16 as Torah-piety, the disposition of contentedness when one has the privilege to listen to and medi- 
tate day and night on the Torah and to trust YHWH to take care of the provisioning for material things. ${ }^{66}$

The way in which the location of Ps 16 within the composition of 15-24 establishes a connection between true happiness and the Torah of YHWH vouches for the conclusion that it was meant by the editors of the Psalter to imply that true piety consists of living according to the Torah of YHWH (under his guidance) and being content with his care and protection (considering this inheritance to be pleasant and beautiful). The privilege of having his counsel and of being in his presence, as well as the prospect of having this privilege extended for ever, neutralises any lack of prosperity. This is also the conclusion of the author of Ps 73. To choose YHWH means to be more than happy and content with whatever he chooses to give to his follower.

Hossfeld and Zenger entertain a view of a linear development of the Davidic Psalter with expansion through various stages. ${ }^{67}$ I suppose it is to allow for the addition of later collections of psalms before 2-89 could be rounded off, that they propose that 16,19 , and 23 must have been added to the cluster 15-24 by the "fourth century" at the latest. The truth is, however, that very little theological development can be discerned between those Torah-wisdom psalms which they date in the "fifth to fourth centuries" and Ps 1 which they date in the "Hellenistic era." ${ }^{68}$ Psalm 1, ${ }^{69}$ Ps $19^{70}$ and Ps $23^{71}$ are all dependent on

66 Ps 119 would later take up the theme of the "desirable gold" from Ps 19 and describe the Torah as comparable to the delight derived from "all riches" (119:14); something in which one can continually "delight" $(119: 24,47,70,77,92)$; an alternative for the desire for "gain" (119:36); comparable to "songs" wherever one has to stay (119:54); better than "thousands of pieces of gold and silver" (119:72); the "heritage" of the psalmist and his "joy" forever (119:111); and including an allusion to Ps 19:11 itself, as something which the psalmist loves more than "gold, even much fine gold" (119:27).

${ }^{67}$ Cf. the summary above. The growth of 3-41 is explained in Hossfeld and Zenger, Psalm 1-50, 14-15. They also state that this is at most an approximation with reservations. Psalms 42-48 are psalms with a diverse origin, collected one after the other. Psalms 51-71 were collected independently and with a different theological aim from 3-41. The 12 psalms of Asaph (50, 73-83) and the Korahite psalms (42-49, 84-85, and 87-88) accumulated around this Davidic collection. When 3-41 and 42-88 were united, the royal psalms $2: 1-9,72$ and 89 were added as hermeneutic horizon so that they could be read in a collective messianic way. Cf. Hossfeld and Zenger, Psalm 1$50,15$.

68 There is an overlap of 23 years between the "fourth century B.C.E." and the "Hellenistic era," but I assume they did not think of these years as a possibility.

69 Psalms 1-2 together constitute a response to the invitation to accept wisdom in Prov 1: The psalmist in Ps 1 accepts the invitation, while the rulers of the world reject 
Prov 1-9, which part of Proverbs must have been completed by the late Persian or early Hellenistic period. ${ }^{72}$ It would thus seem that Pss 19 and 23, at least, must have originated and were inserted into the cluster later than the beginning of the Hellenistic period. If Ps 16 was inserted into the cluster at the same time as these two psalms, there is good reason to believe that it originated at more or less the same time as Pss 1,19 and $23 .^{73}$ There is good reason to believe that it did, since there are many similarities between Pss 1 and $16 .^{74}$ It is also more logical to accept that there was one wisdom redaction of the Psalter which was active towards the very end of its compilation, in the Hellenistic era. It was probably those editors who inserted Pss 16, 19, and 23 and many other wisdom compositions of their own into the Psalter.

\section{F CONCLUSION}

With its focus on living joyfully in the presence of YHWH and under the guidance of his Torah, the cluster 15-24 reflects the exact same sentiments as Ps 1 . It is possible that Ps 1 was composed later than Ps 16, 19 and 23 to serve as a summary of the values reflected in them, but it seems improbable that it was added only very much later. In terms of the Torah as a guide on the road of life and a means to experience being continually in the presence of YHWH and having the privilege of his abundant care and nourishment, Pss 1, 16, 19, 23 and 73 could all have been composed within a short span of time by the same group of people. It is even possible that Ps 16 was inserted in its present position at the same time as when Ps 1 was being prepared to serve as the introduction to the whole Psalter.

the invitation. Cf. Bernard Gosse, L'influence du livre des Proverbes sur les rédactions bibliques à l'époque Perse (TranseuSup 14; Paris: Gabalda, 2008), 51-57.

70 Cf. Gosse, L'influence, 63-66.

71 Cf. Botha, "Following," 283-300.

72 Cf. James A. Loader, Proverbs 1-9 (HCOT; Leuven: Peeters, 2014), 9.

73 Lies, Der Weg des Lebens, 111-114, uses (inter alia) its late linguistic characteristics; the wisdom terminology and wisdom motifs it displays; its thematic proximity to Trito-Isaiah (57:6); the social and religious circumstances it displays; and the similarity to Ps 73 to date it to the late post-exilic time (5th/4th Century B.C.E.), but before Ps 73. In my view, Ps 16 reflects the same theological perspective as Ps 73.

74 E.g. the way in which the poet of Ps 16 dissociates himself from idol worshippers, using חפץץ like the description of dedication to the Torah in 1:2; the description of pious living as the "path of life" (cf. the "road of the righteous" in 1:6); the nocturnal instruction by YHWH in 16:7 (cf. the meditation on the Torah during the night in Ps 1:2); taking counsel from YHWH (יעץ) in 16:7 (cf. the avoidance of the counsel of the wicked, עצה, in 1:1); and the privilege of having YHWH as a companion on the road of life in 16:8 and 1:6. 


\section{BIBLIOGRAPHY}

Barbiero, Gianni. Das erste Psalmenbuch als Einheit, eine synchrone Analyse von Psalm 1-41. Österreichische Biblische Studien 16. Frankfurt am Main: Europäischer Verlag der Wissenschaften, 1999.

Berges, Ulrich. “'God staat aan de kant van die armen' (Ps 109,31): Armoede en Rijkdom in het Psalmenboek." Tijdschrift voor Theologie 44 (2004): 108-123.

Botha, Phil J. "Following the 'Tracks of Righteousness' of Psalm 23." Old Testament Essays 28 (2015): 283-300.

Brown, William P. “'Here Comes the Sun!': The Metaphorical Theology of Psalms 15-24." Pages 258-277 in The Composition of the Book of Psalms. Edited by Erich Zenger. Bibliotheca Ephemeridum Theologicarum Lovaniensum 238. Leuven: Peeters, 2010.

Coppens, Joseph. Het onsterfelijkheidsgeloof in het Psalmboek: avec un résumé en français et une bibliographie du sujet. Mededelingen van de Koninklijke vlaamse academie voor wetenschappen, letteren en schone kunsten van België. Brussel: Paleis der Academiën, 1957.

Dietrich, Walter, Ludwig Köhler, Samuel Arnet, Manfried Dietrich. Konzise und aktualisierte Ausgabe des Hebräischen und aramäischen Lexikons zum Alten Testament (KAHAL). Leiden: Brill, 2013.

Gosse, Bernard. "Le livre des Proverbes, la Sagesse, la Loi et le Psautier." Etudes Théologiques et Religieuses 81 (2006) : 387-394. . L'influence du livre des Proverbes sur les rédactions bibliques à l'époque Perse. Supplément no 14 à Transeuphratène. Paris: Gabalda, 2008.

Groenewald, Alphonso. “The Ethical 'Way' of Psalm 16." Pages 501-511 in The Composition of the Book of Psalms. Edited by Erich Zenger. Bibliotheca Ephemeridum Theologicarum Lovaniensum 238. Leuven: Peeters, 2010.

Liess, Kathrin. Der Weg des Lebens: Psalm 16 und das Lebens- und Todesverständnis der Individualpsalmen. Forschungen zum Alten Testament II/5. Tübingen: Mohr Siebeck, 2004.

Loader, James A. Proverbs 1-9. Historical Commentary on the Old Testament. Leuven: Peeters, 2014.

Hartenstein, Friedhelm. "'Schaffe mir Recht, JHwH!' (Psalm 7:9): Zum theologischen und anthropologischen Profil der Teilkomposition Psalm 3-14.” Pages 229-258 in The Composition of the Book of Psalms. Edited by Erich Zenger. Bibliotheca Ephemeridum Theologicarum Lovaniensum 238. Leuven: Peeters, 2010.

Hossfeld, Frank-Lothar and Erich Zenger. Psalm 1-50. Volume 1 of Die Psalmen. Die Neue Echter Bibel. Würzburg: Echter Verlag, 1993.

Miller, Patrick D. "Kingship, Torah Obedience and Prayer." Pages 127-142 in Neue Wege der Psalmenforschung: Für Walter Beyerlin. Edited by Klaus Seybold and Erich Zenger. Herders Biblische Studien 1. Freiburg: Herder, 1994.

Mindling, Joseph A. "Hope for a Felicitous Afterlife in Psalms 16, 49 and 73." Laurentianum 32 (1991): 305-369.

Nötscher, Friedrich. Die Psalmen. Echter-Bibel, Alte Testament. Würzburg: EchterVerlag, 1947.

Seybold, Klaus. Die Psalmen. Handbuch zum Alten Testament I/15. Tübingen: J. C. B. Mohr [Paul Siebeck], 1996.

Sumpter, Philip. “The Coherence of Psalms 15-24.” Biblica 94 (2013): 186-209. 
84 Botha, "True Happiness," OTE 29/1 (2016): 61-84

Tucker, W. Dennis. "Democratization and the Language of the Poor in Psalms 2-89." Horizons in Biblical Theology 25 (2003): 161-178.

. "Psalms 1: Book of." Pages 578-593 in Dictionary of the Old Testament: Wisdom, Poetry \& Writings: A Compendium of Contemporary Biblical Scholarship. Edited by Tremper Longman III and Peter Enns. The IVP Bible Dictionary Series. Downers Grove, Ill.: Intervarsity Press, 2008.

Van der Lugt, Pieter. Cantos and Strophes in Biblical Hebrew Poetry with Special Reference to the First Book of the Psalter. Oudtestamentische Studiën. Leiden: Brill, 2006.

Van der Ploeg, Johannes P. M. Psalm $1 \mathrm{t} / \mathrm{m}$ 75. Volume 1 of Psalmen. De Boeken van het Oude Testament. Roermond: J.J. Romen \& Zonen, 1973.

Weber, Beat. "Notizen zu Form, Pragmatik und Struktur von Psalm 16." Biblische Notizen 125 (2005): 25-38.

Zenger, Erich. "Psalmenexegese und Psalterexegese: Eine Forschungsskizze." Pages 17-65 in The Composition of the Book of Psalms. Edited by Bibliotheca Ephemeridum Theologicarum Lovaniensium 238. Leuven: Peeters, 2010.

Phil J. Botha, Department of Ancient Languages, University of Pretoria, 0002, Pretoria.Email: phil.botha@up.ac.za. 